\title{
RANCANG BANGUN ALAT PENGGILINGAN CABAI MENGGUNAKAN MOTOR LISTRIK
}

\author{
Yusdin Gaga ${ }^{1)}$, Sjahril Botutihe ${ }^{2)}$, Sirajuddin Haluti ${ }^{3)}$ \\ ${ }^{1)}$ Mahasiswa Program Studi Mesin dan Peralatan Pertanian, Politeknik Gorontalo \\ ${ }^{2,3}$ Dosen Program Studi Mesin dan Peralatan Pertanian, Politeknik Gorontalo
}

\begin{abstract}
ABSTRAK
Penelitian ini dilakukan untuk mengetahui cara merancang bangun alat penggilingan cabai menggunakan motor listrik.Hasil penelitian menunjukan bahwa rancang bangun alat penggilingan cabai menggunkan motor listrik. Diketahui bahwa hasil pembuatan konstruksi alat peggiling cabe dilakukan dilaboratorium Mesin Peralatan pertanian,Kemudian mekanisme penggerak yang digunakan adalah puli pengantar dengan perbandingan hasil pengujian dalam penggiling cabai menggunakan metode Model Konvensional /manual, kemudian model alat penggilingan menggunakan motor listrik, dan pada prosedur pengujian melalui tahapan siapkan timbangan, apabila proses sudah siap langkah selanjutnya berupa buah cabe, penggilingan pada sebuah alat penggiling menggunakan motor listrik, tuangkan buah cabe kedalam hoper pada saat proses penggiligan,kemudian untuk prose pengujian dilakukan dengan membedakan proses secara manual dan menggunakan motor listrik penggilingan cabe.
\end{abstract}

Kata Kunci: Alat Penggilingan Cabai, Motor Listrik.

\section{DESIGN OF CHILDREN MILLING TOOLS USING ELECTRIC MOTOR}

\begin{abstract}
This study was conducted to determine how to design a milling tool wake chili using the motor listrik.Hasil research shows that the design of the grinding tool chili using the electric motor. It is known that the results of the construction of chili peggiling tools are carried out in the Agricultural Equipment Machine laboratory. Then the driving mechanism used is an introduction pulley with a comparison of the test results in a chili grinder using the Conventional Model / manual method, then the grinding tool model using an electric motor, and the testing procedure through the stages prepare the scales, if the process is ready the next step in the form of chillies, grinding on a grinder using an electric motor, pour the chilli fruit into the hoper during the grinding process, then for the testing process is done by differentiating the process manually and using an electric motor chili grinding.
\end{abstract}

Keywords: Chili Milling Tool, Electric Motor.

\section{PENDAHULUAN}

Tanaman cabai Dindonesia. Tanaman cabai tumbuh kira-kira sejak 2500 tahun sebelum Masehi. Masyarakat yang pertama kali memanfaatkan dan mengembangkan cabai adalah orang Inca di
Amerika Selatan, orang Maya di Amerika Tengah, dan orang Aztek di Meksiko. Mereka memanfaatkannya sebagai bumbu masakan. Christopher Colombus yang mendarat di pantai San Salvador pada tanggal 12 Oktober 1492 menemukan penduduk setempat banyak yang 
menggunakan buah merah menyala berasa pedas sebagai bumbu masakan. (Ferdinan Magelhaens 1480-1521).

Tanaman cabai Di Indonesia memilki sentra produk dengan berbagai jenis dan varietas, dan tumbuh dibeda tempat diantaranya sumatera dan kalimantan (pengomsumsi) cabai terbanyak dikalimantan. Bentuk buah cabai yang dikelompokan atas beberapa macam yaitu, bagus dan kurang bagus, Sedangan yang dipasarkan oleh pedagang adalah buah yang masih bagus.

Di sumatera, Kalimantan panen buah cabai untuk dikomsumsi lokal dan dipetik saat panen (buah dalam kondisi masak panen), sehingga tidak perlu di ulek atau dan cara penggilingannya mudah, sedangkan yang dipasarkan di Jawa atau dipanen (saat merah/belum merah) buah cabai yang dipasarkan di jawa adalah cabai yang belum merah dan kurang baik.

Penggiling yang pernah ada penghaluscabai sangat bermanfaat akan tetapi penghalusan pada blender ini masih membutuhkan waktu yang lama dan masih menggunakan air pada saat penghalusan sekaligus tidak dapat menghancurkan biji dari cabai tersebut atau belum hancur dan kehalusan atau keleme3butan cabai belum maksiamal.

Berdasarkan hal tersebut maka penulis membuat alat penggilingan cabai, memiliki sebuah kehalusan yang berbeda jika dibandingkan dengan cara manual yang masih menggunakan air atau biji dari cabai tersebut masih utuh dan proses kehalusannya belum maksimal,maka dari itu perlu membuat alat penggilingan cabai kinerja yang lebih efektif dengan waktu yang di butuhkan saat proses penggilingan menggunakan mesin giling makin mudah pada saat pengglingan cabaiatau penghalusan.

\section{TINJAUAN PUSTAKA}

\section{Tanaman Cabe}

Cabe adalah merupakan tumbuhan yang dikelompokkan dalam anggota genus Capsicum. Buah cabe dapat juga digolongkan sayuran maupun bumbu, tergantung bagaimana digunakan. Sebagai bumbu, buah cabai yang pedas sangat populer di Asia Tenggara sebagai penguat rasa makanan. (Kilham 2006 Bano dan Sivaramakirinhan 1980).

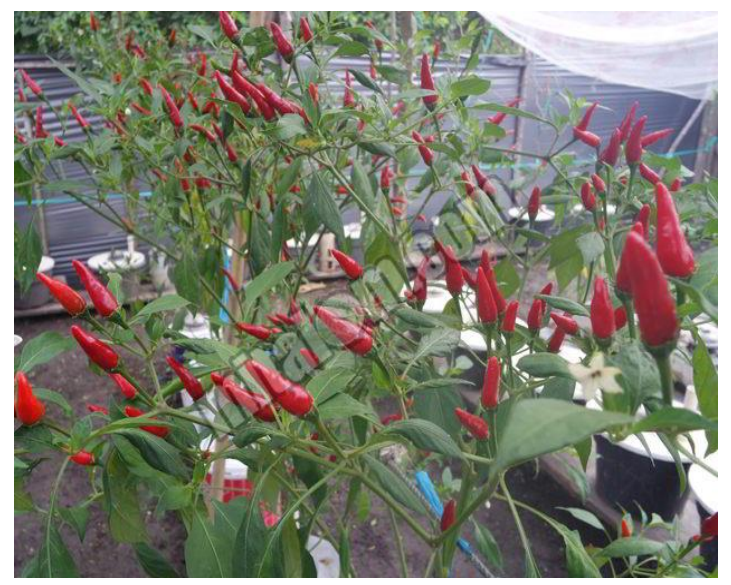

Gambar 1.1 pada cabai merah (C.frutecnes).

Cara menanam cabai memang tergolong sudah banyak diketahui oleh masyarakat Indonesia, khususnya masyarakat yang tinggal di pedasaan. Umumnya cabe ditanam pada tanah yang kaya humu, gembur dan tidak tergenang air. Waktu tanam yang baik untuk lahan kering adalah pada akhir musim hujan, yaitu sekitar bulan Maret hingga April. Sementara untuk memperoleh harga yang tinggi, maka penanaman bisa dilakukan pada bulan Oktober dan panen pada bulan Desember, walaupun sangat besar resiko kegagalan panen (Adiyoga dan Soetiarso 1999).

Untuk menaman cabai, maka beberapa hal yang harus diperhatikan adalah pemilihan bibit yang tepat, pembuatan semaian, persiapan lahan, penanaman dan lain sebagainya. Untuk memperjelas masing-masing proses penanaman cabe mulai dari awal hingga panen, maka berikut adalah penjelasannya secara detail yang akan dipublikasikan kepada Anda:( Casweell danmodjusca 1996).

\section{Syarat Tumbuh Cabai}

Pada umumnya tanaman cabai merah dapat ditanam di dataran tinggi maupun dataran rengah, yaitu antara 500-1.200 m diatas permukaan laut. Yang terdapat di seluruh Indonesia terutama di Pulau Jawa. Meskipun luas lahan yang cocok untuk cabai masih sangat luas tetapi penanaman cabai di dataran tinggi masih sangat terbatas. Perkembangan tanaman cabai merah lebih diarahkan ke areal perkembangan dengan ketinggian sedikit dibawah $800 \mathrm{~m}$ diatas permukaan laut. Terutama pada lokasi yang air irigasinya sangat terjamin sepanjang tahun (Prayudi, 2010). 


\section{Alat Penggiling Cabe}

Mesin Penggiling Cabai merupakan sebuah yang berfungsi untuk menghancurkan cabai,selain menggilingan cabai dan bumbu masak terdapat beberapa mesin yang bisa mengatur sesuai seperti yang diinginkan disesuaikan dengan kebutuhan.jika dilihat dari bentuk mesin giling cabai adalah dengan cara yang menggilas bahan (cabai).selain ini mesin belum maksimal pada saat proses penggilingan biji dari cabe masih utuh..

Mesin giling cabai adalah suatu mesin yang dipergunakan dalam proses penggilingan aneka bumbu yakni cabe dan bumbu basah lainnya. Mesin penggiling bumbu merupakan mesin produksi Agrowindo yang mendesain mesin dengan manfaat membantu kemudahan untuk proses memasak. Ada banyak hal yang dapat Anda lakukan lewat mesin penggiling cabe yakni menggiling cabe, bawang putih, bawang merah, kunyit, jahe, kemiri dan bumbu basah yang lainnya. Cara kerja mesin penggiling bumbu yakni dengan menggiling aneka bahan lewat batu grindra yang dapat diatur jaraknya guna menghasilkan tingkat kelembutan yang mudah untuk disesuaikan. Batu grindra memiliki perananan penting untuk menentukan tekstur bumbu yang diinginkan baik kasar ataupun halus. Untuk para pengusaha kulner masakan tentu memiliki mesin giling cabe akan membantu melancarkan proses memasak yang mudah dan lebih gampang. Penggunaan mesin giling cabe ini sangat cocok bagi para pelaku bisnis kuliner seperti warung, rumah makan, restoran, café, hotel, catering dan lainnya. Jika Anda menggunakan mesin giling cabe tentu dalam menyajikan masakan kuliner akan lebih mudah dan gampang. Mesin penggiling bumbu merupakan mesin investasi yang tepat dalam bisnis kuliner.

\section{Alat Penggilingan Cabai}

Mesin Penggiling Cabai merupakan sebuah yang berfungsi untuk menghancurkan cabai,selain menggilingan cabai dan bumbu masak terdapat beberapa mesin yang bisa mengatur sesuai seperti yang diinginkan disesuaikan dengan kebutuhan.jika dilihat dari bentuk mesin giling cabai adalah dengan cara yang menggilas bahan (cabai). selain ini mesin belum maksimal pada saat proses penggilingan biji dari cabe masih utuh.
Mesin giling cabai adalah suatu mesin yang dipergunakan dalam proses penggilingan aneka bumbu yakni cabe dan bumbu basah lainnya. Mesin penggiling bumbu merupakan mesin produksi Agrowindo yang mendesain mesin dengan manfaat membantu kemudahan untuk proses memasak. Ada banyak hal yang dapat Anda lakukan lewat mesin penggiling cabe yakni menggiling cabe, bawang putih, bawang merah, kunyit, jahe, kemiri dan bumbu basah yang lainnya. Cara kerja mesin penggiling bumbu yakni dengan menggiling aneka bahan lewat batu grindra yang dapat diatur jaraknya guna menghasilkan tingkat kelembutan yang mudah untuk disesuaikan. Batu grindra memiliki perananan penting untuk menentukan tekstur bumbu yang diinginkan baik kasar ataupun halus. Untuk para pengusaha kulner masakan tentu memiliki mesin giling cabe akan membantu melancarkan proses memasak yang mudah dan lebih gampang. Penggunaan mesin giling cabe ini sangat cocok bagi para pelaku bisnis kuliner seperti warung, rumah makan, restoran, café, hotel, catering dan lainnya. Jika Anda menggunakan mesin giling cabe tentu dalam menyajikan masakan kuliner akan lebih mudah dan gampang. Mesin penggiling bumbu merupakan mesin investasi yang tepat dalam bisnis kuliner.

\section{Referensi Alat Penggilingan Cabai}

Penggiling cabe dan bumbu basah fungsi mesin ini menggiling cabe dan bumbu basah dengan kelembutan yang bisa diaturSistem mesin giling cabai ini adalah menggilas bahan dengan batu grinda. Kelembutan hasil giling bisa diatur dengan cara mengatur jarak batu grinda, yang mudah untuk dilakukan.

\section{Mesin stainless stell untuk yang kontak bahan}

2. Kelembutan produk bisa diatur hanya dengan memutar

3. Hasil gilingan maksimal misalnya saat penggilingan cabai, biji cabai bisa tergiling. Bandingkan dengan manual masih utuh .

4. Spare part teredia ( batu grinda, dll )

5. Teruji siap pakai penguji kuliner diberbagai kota Indonesia dan manca negara.

Mesin giling konvesional semacam manual bumbu masak masuk dalam incaran para pengusaha kuliner, banyak dariyang menfungsikan mesin 
manual sebagai mesin giling cabai terdapat kelemahan yang dimilki oleh mesin penggiling cabai.

1. Kapasitas karena hanya mampu menampung 1-3 liter persatu kali giling mesin juga dapat panas sehingga mampu bekerja 20 menit saja

2. Menggunakan bahan beresiko atau bahan yang dapat bereaksi terhadap panas

3. Biasanya tidak dapat menghancurkan biji bji cabai

4. Perlu tambahan air untuk menghaluskan kadang dalam jumlah yang sedikit Sehingga dapat merusak keseluruhan rasa

\section{Efisiensi waktu}

$$
\mathbf{E}=\underline{\mathbf{A}_{1}} \mathbf{x} \mathbf{1 0 0} \%
$$

$\mathbf{A}_{2}$

Keterangan :

$$
\begin{aligned}
& \mathbf{E}=\text { Efisiensi waktu } \\
& \mathbf{A}_{1}=\text { Alat yang direncanakan ( menit ) } \\
& \mathrm{A}_{2}=\text { Alat yang sebelumnya ( menit ) }
\end{aligned}
$$

\section{Alat Pembanding}

Kekurangan dari alatmanual ini pada proses berputar atau penggilingan penghalusan membutuhkan waktu yag lama jika dibandingkan dengan menggunakan motor listrik lebih cepat proses penggilingan karena dapat membantu masyarakat penggunaan mesin mesin giling sangat cocok bagi para kulner yang mudah atau lebih gampang dan memiliki tekstur yang lebih halus.

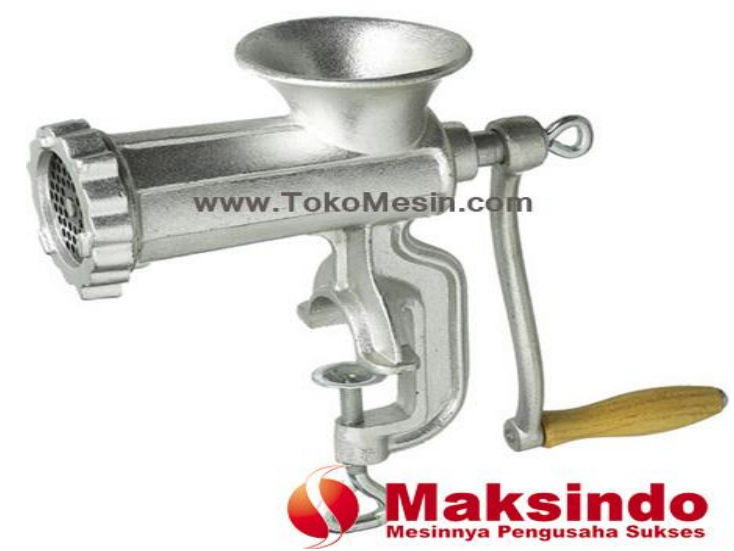

Gambar 2.1 penggilingan cabe secara manual

\section{METODE PENELITIAN}

\section{Diagram Alir}

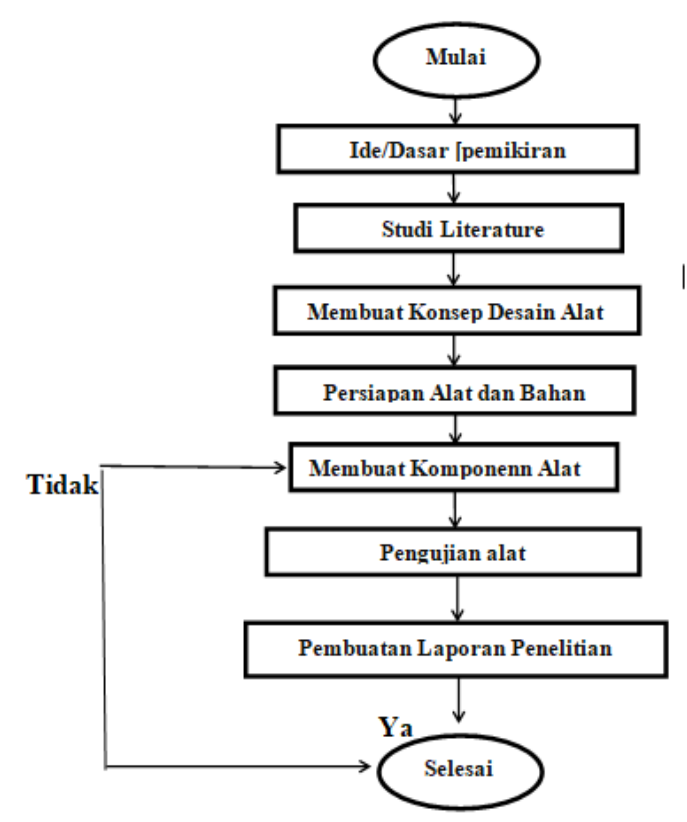

Gambar 3.1. Diagram Alir Penelitian.

Dalam susunan diagram alir beberapa tahap yang harus perlu kita ketahui proses penelitian pabrikasi dan pengujian alat mesin penggiling cabai menggunakan motor listrik. Yaitu dengan mengetahui skema hasil yang di uji dengan efisiensi waktu penggilingan cabai.

\section{Kebutuhan Alat Dan Bahan}

\section{Alat}

Pada proses perancangan alat menggunakan alat berupa komputer, software gambar, alat tulis dan mistar. Pabrikasi menggunakan berupa mesin las, gurinda, bor tangan, circular saw, obeng plus, obeng minus, mesin bubut, martil, mesin frize, kuas, kompresor, meteran, jangka sorong, alat tulis, kamera, dan sepeda motor listrik.

\section{Bahan}

Bahan yang akan digunakan pada alat penggiling cabai yaitu bahan untuk pabrikasi.untuk proses pabrikasi bahan digunakan adalah cat, tinner besi segitiga, elektroda, mata gurinda, mata bor, baut, mata 
bubut, bearing. Pengujian yang digunakan pada alat ini motor listrik.dan buah cabai.

\section{Desain Alat Penggiling Cabe}

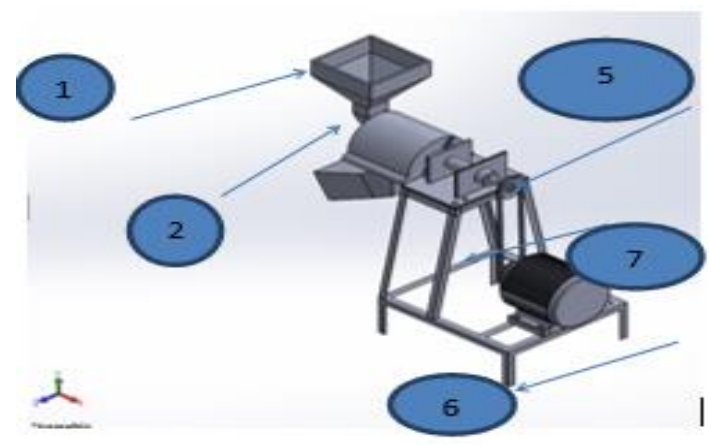

Gambar 3.2 Desain Alat Penggilingan Cabe

Keterangan :

1. input

2.pemutar

3.poros

4.v belt

5.ruang pemgupas

6.rangka alat

7. motor listrik

\section{Perancangan struktual}

\section{$>$ Ruang pengupas}

Ruang pengupas berfungsi untuk menggiling cabai dimana sebuah mata pisau akan memotong cabai hingga halus dengan kekuatan motor listrik mencapai $250 \mathrm{wt}$ dan dengan kapasitas ruang pencacah yang mampu menampung cabai hingga mendapatkan pengupasan atau pemotongan yang halus.

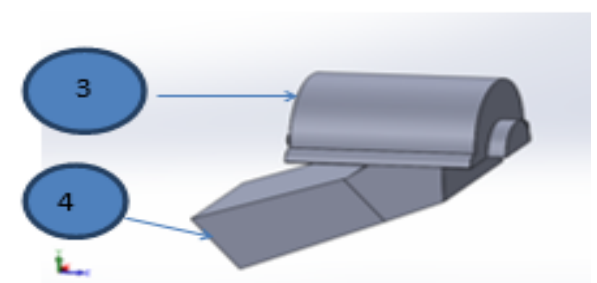

Gambar 3.3 ruang pengupas

\section{> Rangka alat}

Rangka alat dengan posisi fertikal berdimensi terbuat besi siku dari untuk dapat menopang mesin dan ruang penghalus cabai.

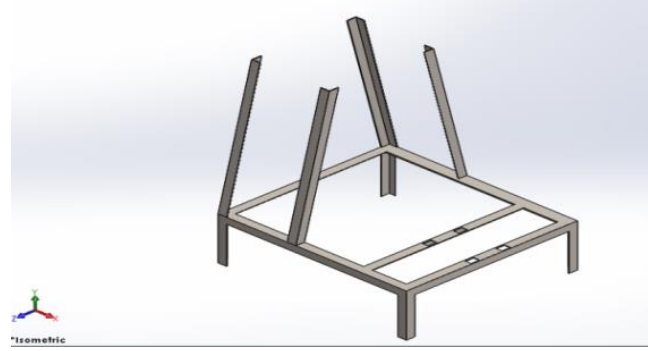

Gambar 3.4 Rangka alat

\section{Puli 1}

Puli berfungsi untuk mentransferkan tenaga putar dari v-belt ke poros untuk proses pemotongan pada cabai.

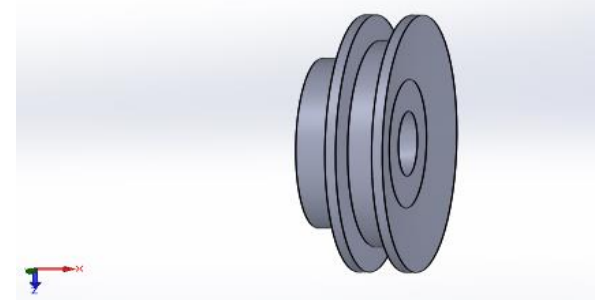

Gambar 3.5. Puli 1

\section{Puli 2}

Puli merupakan salah satu dari berbagai macam transmisi. Puli dalam bahasa Inggris yaitu pulley (mungkin kata puli berasal dari kata pulley). Puli berbentuk seperti roda. Pada penggunaannya puli selalu berpasangan dan dihubungkan dengan sabuk (belt).
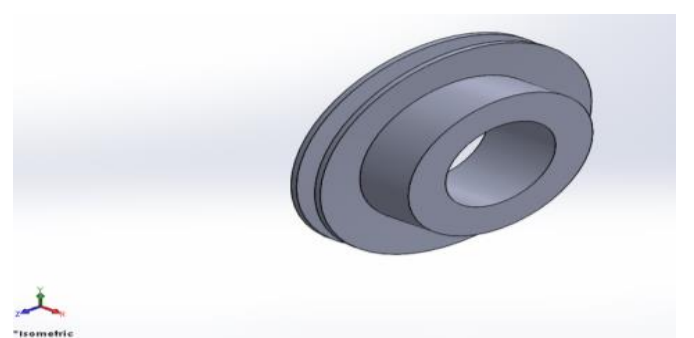

Gambar 3.6 puli 2

\section{Poros}

Poros engkol menjadi suatu komponen utama dalam suatu mesin pembakaran dalam. menjadi pusat poros dari setiap gerakan piston. 
Pada umumnya $\mathrm{t}$ berbahan besi cor karena harus dapat menampung momen inersia yang dihasilkan oleh gerakan naik turun piston. Sehingga fungsi utama dari $\mathrm{t}$ adalah mengubah gerakan naik turun yang dihasilkan oleh piston menjadi gerakan memutar yang nantinya akan diteruskan ke transmisi. Crankshaft harus terbuat dari bahan yang kuat dan mampu menahan beban atau momen yang kuat karena harus menerima putaran mesin.

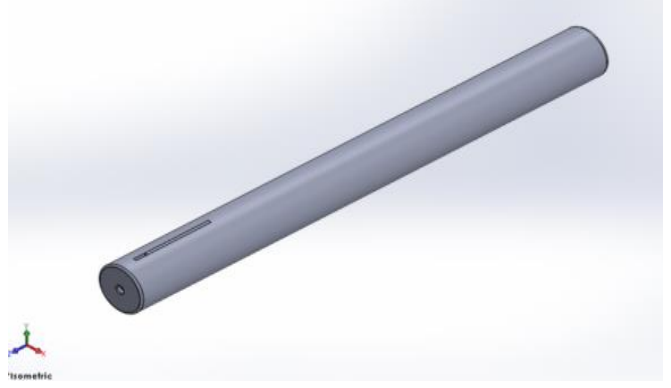

Gambar 3.7 Poros

\section{Pemutar}

Pemutar halus berfungsi untuk menaikkan dan menurunkan proses penghalusan cabi secara lambat, dan bentuknya lebih kecil.

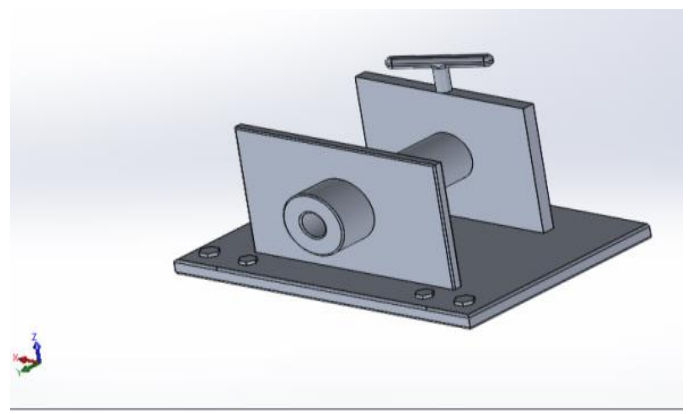

Gambar 3.8 Pemutar

\section{Motor Listrik}

Motor listrik adalah alat untuk mengubah energi listrik menjadi energi mekanik. Alat yang berfungsi sebaliknya, mengubah energi mekanik menjadi energi listrik disebut generator atau dinamo.
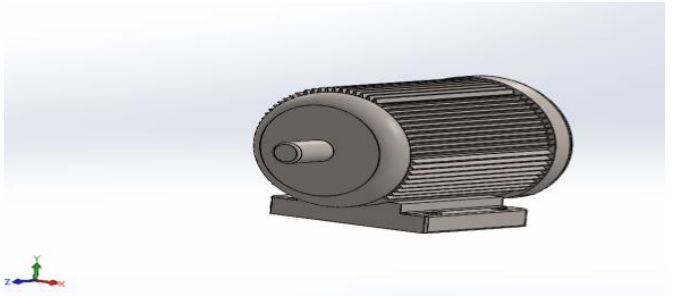

Gambar 3.9 Motor listrik

\section{Mata Pisau}

Penghancuran dilakukan penerapan pada penghalusan yang akhirnya menyebabkan buah cabai menjadi halus .mata pisau ini beoperasi pada penggilingan ataupun penghalusan pada buah cabai.

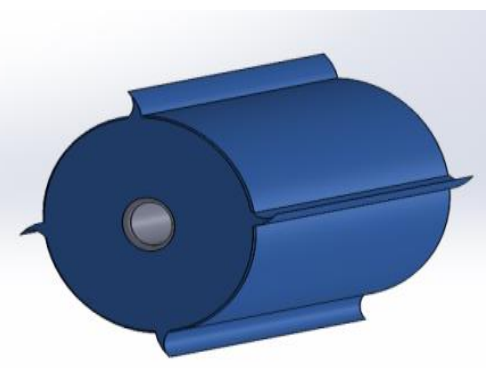

Gambar 3.10 Mata Pisau

\section{Input}

Berfungsi untuk memasukan cabai ke dalam ruang pengupas.

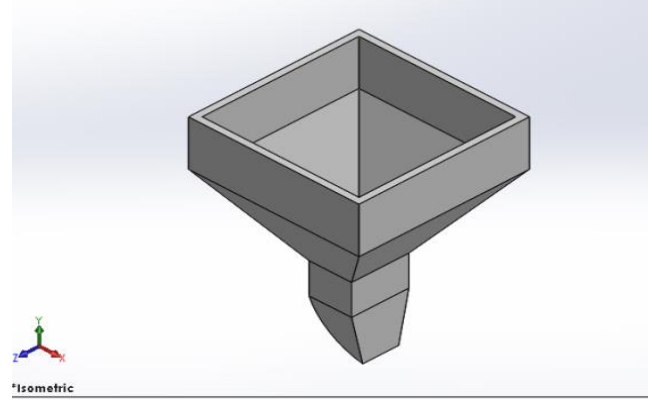

Gambar 3.11. Input

\section{V-Belt}

berfungsi sebagai penyambung daya poros yang satu ke poros yang lain melalui pully seiring mengikuti laju putaran pada mesin atau alat yang dikaitkan

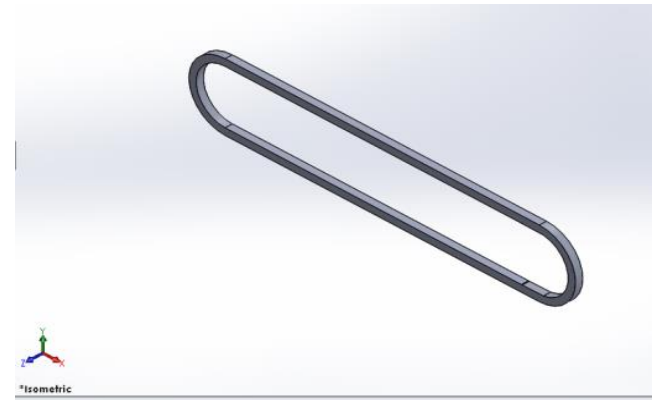

Gambar 3.12 V-belt. 


\section{HASIL DAN PEMBAHASAN}

\section{Hasil Rancangan alat}

Hasil pembuatan konstruksi alat peggiling cabe dilakukan pada dilaboratorium Mesin Peralatan Pertanian (MPP). Gambar 4.1 menunjukkan alat penggilingcabe menggunakan motor lisrtik sebagai berikut :

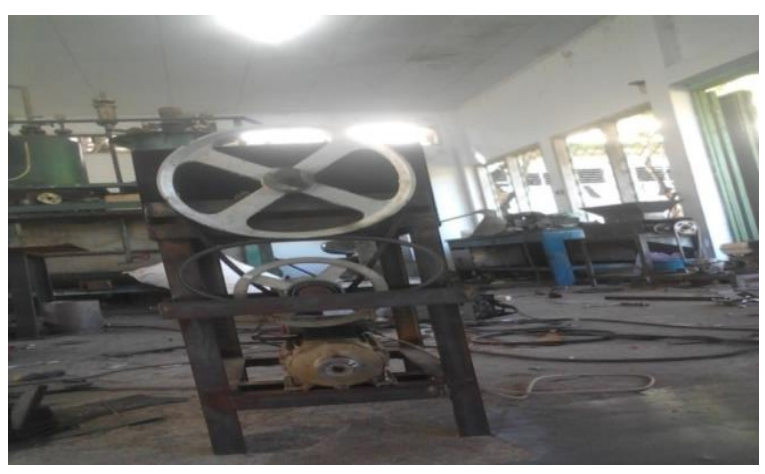

Gambar 4.1 hasil rancang gambar alat penggilin cabe

Hasil rancangan konstruksi pada Gambar 4.1 diketahui bahwa mesin penggerak menggunakan motor listrik. Kemudian mekanisme penggerak yang digunakan adalah puli pengantar.

\section{Model alat penggilingan menggunakan motor listrik}

Alat penggilingcabe merupakan solusi yang tepat dapat digunakan untuk membantu para ibu rumah tangga dalam proses penggilingan pada tanamannya. Akan tetapi model alat penggiling yang tersedia dipasaran yang secara manual tidak semuanya memiliki kinerja yang sesuai kebutuhan masyarakati. Gambar 4.3 menunjukkan perbandingan Alat penggilingan cabe yang standar dan termodifikasi.

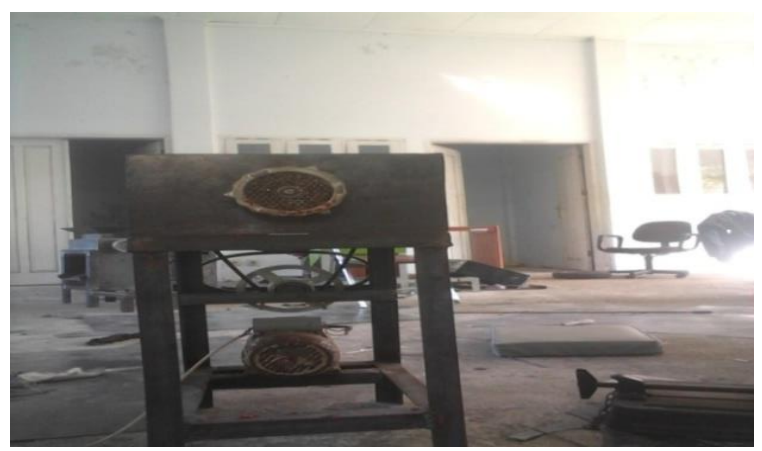

Gambar 4.2 penggilingan cabemenggunakan motor listrik standar

\section{PENUTUP}

\section{Kesimpulan}

Berdasarkan hasil pengujian kesimpulan sebagai berikut :Dengan jumlah cebe $0.5 \mathrm{~kg}$ pada putaran motor listrik $2135 \mathrm{rpm}$ menghasilkan persentasi tertinggi pada pengujian sebesar pertama $80 \%$ cabe yang keluar. Sedangkan pengujian yang waktu yang tersingkat $70 \%$ pada cabe yang keluar dari alat.

\section{Saran}

Pada saat proses penggilingan pada alat ini, disarankan lebih memperhatikan proses penggilingan pada saat menggunakan motor listrik .karena disaat penggilingan mata pisau berputar menghasilkan tinggi pada putaran pengujian alat.

\section{DAFTAR PUSTAKA}

Agrowindo. 2015 'Mesin Penggiling cabe Stainless Steel'. Avaible $a t$ :http//mesinpertanian.com/mesin-penilincabe-stainless-steel/.

Pertanian, D.J.H.K.2013” No TitleKlasifikasi dan Morfologi lengkap Tanaman Cabai ( Capsicum annum. )

Prayudi .2010 'Syarat Tumbuh Tanaman Cabai pembenihan Sampai Panen'.

Available at: https://ulydays.com/syarat-tumbuhtanaman-cabai/.

Sivaramakrishnan, K.B dan 2006 'Cabai' 